\title{
Antimicrobial use in Chinese swine and broiler poultry production
}

Vikram Krishnasamy ${ }^{1 *}$, Joachim Otte ${ }^{2}$ and Ellen Silbergeld ${ }^{3}$

\begin{abstract}
Background: Antimicrobial use for growth promotion in food animal production is now widespread. A major concern is the rise of antimicrobial resistance and the subsequent impact on human health. The antimicrobials of concern are used in concentrated animal feeding operations (CAFOs) which are responsible for almost all meat production including swine and poultry in the US. With global meat consumption rising, the CAFO model has been adopted elsewhere to meet this demand. One such country where this has occurred is China, and evidence suggests $70 \%$ of poultry production now occurs outside of traditional small farms. Moreover, China is now the largest aggregate consumer of meat products in the world. With this rapid rise in consumption, the Chinese production model has changed along with the use of antimicrobials in feeds. However, the specific antibiotic use in the Chinese food animal production sector is unclear. Additionally, we are aware of high quantities of antimicrobial use because of reports of high concentrations of antimicrobials in animal waste and surface waters surrounding animal feeding operations.
\end{abstract}

Methods: In this report, we estimate the volume of antibiotics used for swine and poultry production as these are the two meat sources with the highest levels of production and consumption in China. We adopt a model developed by Mellon et al. in the US for estimating drug use in feed for poultry and swine production to estimate overall antimicrobial use as well as antimicrobial use by class.

Results: We calculate that 38.5 million kg [84.9 million Ibs] were used in 2012 in China's production of swine and poultry. By antibiotic class, the highest weights are tetracyclines in swine and coccidiostats in poultry.

Conclusions: The volume of antimicrobial use is alarming. Although there are limitations to these data, we hope our report will stimulate further analysis and a sense of urgency in assessing the consequences of such high levels of utilization in terms of antibiotic resistance in the food supply and the environment.

Keywords: Agriculture, Anti-bacterial agents, Animals, China, Microbial drug resistance, Poultry, Swine, Food supply

\section{Background}

The use of antimicrobials in food animal production is now well known in the US and many other countries [1]. Antimicrobial use in feeds for food animal production first started in the 1940s when they were added to feeds used in broiler poultry production [2]. It was claimed that chickens gained more weight in a shorter amount of time resulting in greater feed efficiency [3,4]. In 1925 , a $1.13 \mathrm{~kg}$ [2.5 lb] chicken could be produced in 112 days. By 1950, this had been cut to 70 days. As of 2010, a chicken weighing greater than $2.27 \mathrm{~kg}$ [5 lbs] can

\footnotetext{
* Correspondence: vkrish11@jhu.edu

'Johns Hopkins University Bloomberg School of Public Health, 615 N. Wolfe Street, Room WB602, Baltimore, MD 21205, USA

Full list of author information is available at the end of the article
}

be produced in less than 50 days [5]. The practice has since been adopted in the production of other food animals in the United States, throughout the developed world, and in lesser-developed countries such as China and Brazil [6,7]. It remains unclear why antimicrobials cause food animals to gain weight more quickly. Some hypothesize that they lead to decreased illness allowing weight to accumulate faster [8,9]. However, no convincing evidence has been produced to support this idea [10].

Prior to the rise in antimicrobial use came a change in how food animals were produced. Small farms were rapidly replaced by operations with much higher densities of animals. In 1950, chickens consumed in the US came from more than 1.5 million farms across the country 
with about 355 chickens per farm [5]. By 2012, there were about 16,000 farms that produced less than 2,000 broilers per year [11]. In addition, by 2012, there were over 15,000 operations that produced greater than 100,000 broilers annually [11]. These trends were repeated in swine production $[11,12]$. Some have attributed lower consumer meat prices to this rise in larger operations [13]. Additionally, preceding this rise of animal feeding operations was a trend towards vertical integration whereby corporations controlled the production chain [14]. Many farmers now raise animals under contract with these corporations and do not own the animals in their operations [13]. This has allowed vertically integrated corporations to dictate terms for each operation [13]. The largest poultry integrators now produce over 500,000 chickens annually, with some corporations controlling thousands of operations [15].

This rise in poultry and swine production has paralleled and driven increases in demand by consumers in the United States. Since 1950, per capita meat consumption in the United States has risen dramatically. One study noted US per capita meat consumption doubled between 1909 and 2007 [16]. Consumption in the European Union also doubled more recently between 1961 and 2003 [16]. Additionally, developing countries have seen marked consumption increases. The World Health Organization notes that consumption in developing countries more than doubled in the second half of the $20^{\text {th }}$ century [17]. It is estimated that annual worldwide meat production will be 376 million metric tons [ 414 million short tons] by
2030, up from 218 million metric tons [240 million short tons] in 1999 [17]. Increasing urbanization, incomes, and populations are significant factors in this trend [7]. While developing country consumption still lags behind developed countries, consumption is rising more rapidly than in developed countries [17-19].

One such country where production and consumption have both increased rapidly is China. Total meat consumption in China is higher than any other country [19]. Total and per capita pork consumption is the highest in the world making pork the most popular meat in China [20]. As of 2012, the Chinese consumed $38.1 \mathrm{~kg}$ [84 lbs] of pork per person annually while Americans consumed $26.8 \mathrm{~kg}$ [59 lbs] per person [21]. In the 1970s, total meat consumption was only one-third of the United States [21]. China surpassed the US in total meat consumption in 1992. Since then, demand has only risen $[18,21]$. Currently, half of the world's living pigs reside in China, more than 470 million. Moreover, in 2011, 660 million swine were produced in China [18]. With rapid urbanization and increasing incomes, we have seen meat consumption continue to increase $[18,20,22]$. And, pork it seems, will remain the most popular meat for the time being [23]. Figure 1 notes the trends in total swine and poultry consumption in the United States and China from 1960 to 2013 [24].

A shift to larger operations has supported increases in Chinese food animal production. In 1998, 30\% of broilers in China were produced on farms that produced greater than 2000 broilers annually. In 2009, this

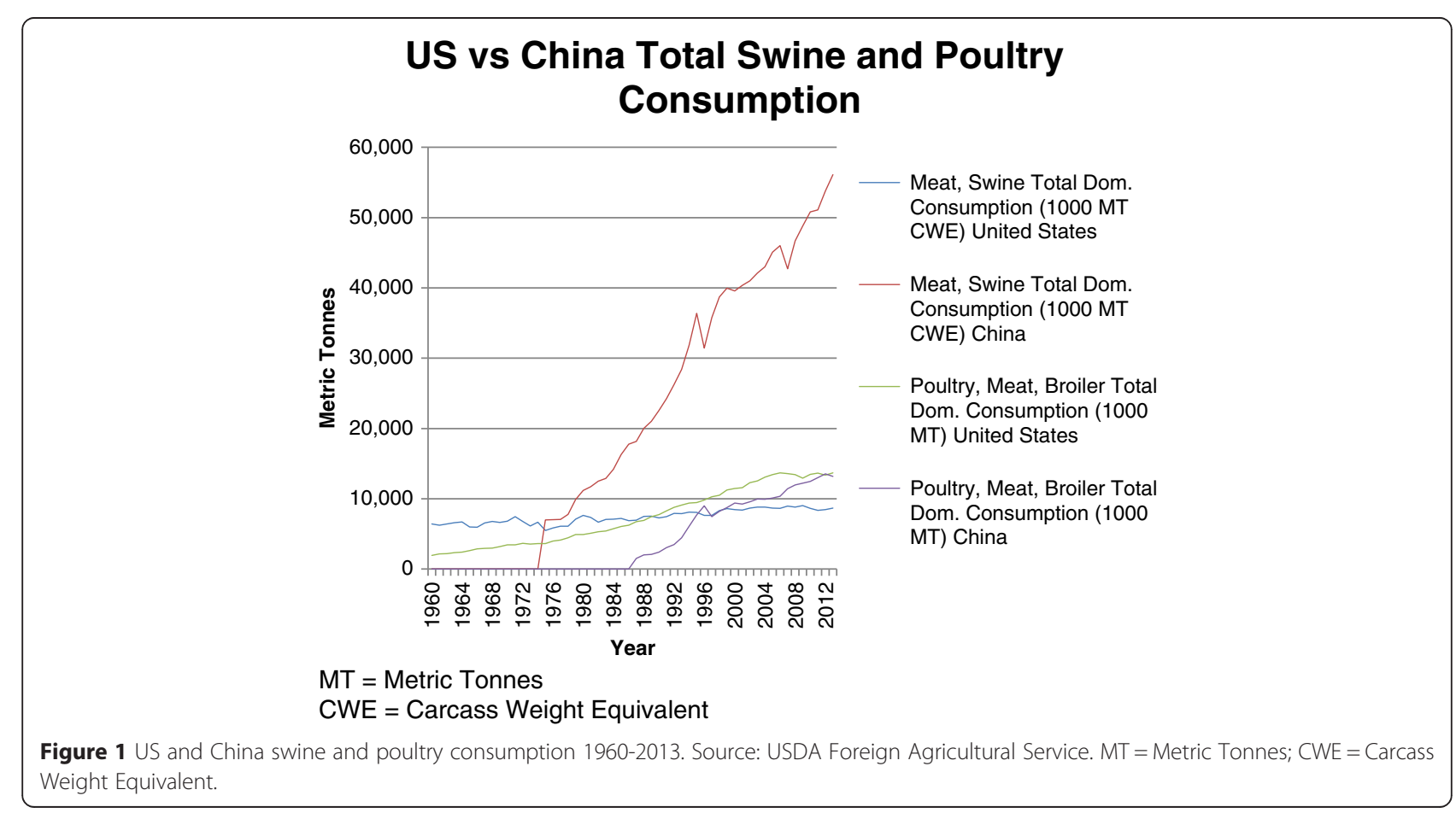


number was 70\% [7,25]. Between 2007 and 2009, the number of poultry operations in China with more than 100,000 broilers increased by $34 \%$ [25]. In 2014, this number is likely to be higher although we do not yet have data to confirm this. Similar rapid intensification has occurred in the pork industry [20]. In 2000, it was estimated that $74 \%$ of swine production occurred on backyard farms with an annual production of 1-49 heads. Commercial farms that produced greater than 1000 heads per year accounted for only $5 \%$ of swine production. By 2010, these commercial farms accounted for $12 \%$ while backyard farms had decreased to $37 \%[20,22]$.

A direct comparison of swine production in the US and China is provided in Table 1 [18]. Between the years 2000 and 2012, there were increases in the number of swine slaughtered in both the US and China. Pig inventories also increased. While the number of swine slaughtered is much larger in China than in the US, carcass weight is still greater in the US. Table 2 provides a comparison between the US and Chinese poultry production industries between the years 2000 and 2012. Again, both countries experienced increases in production. Additionally, carcass weights remain higher in the US than in China.

As a result of rising production and the shift to larger animal feeding operations, there is a concern about the adverse consequences of these systems [20]. This is especially true in China where high consumption of meat among a population of 1.3 billion and the shift to intensive agricultural practices have led to environmental

Table 1 Chinese and US swine industry comparisons

\begin{tabular}{llll}
\hline & $\mathbf{2 0 0 0}$ & $\mathbf{2 0 1 2}$ & Change (\%) \\
\hline China & & & \\
Pig inventory & $388,298,000$ & $465,500,000$ & 19.9 \\
No slaughtered & $468,796,366$ & $670,949,440$ & 43.1 \\
Carcass weight (kg) & 76.5 & 73.2 & -4.3 \\
Production (tonnes) & $35,862,922$ & $49,113,499$ & 36.9 \\
Offtake rate & 1.21 & 1.44 & 19.0 \\
Prod (kg)/Invent & 92.36 & 105.51 & 14.2 \\
\hline USA & & & \\
Pig inventory & $59,342,000$ & $66,412,800$ & 11.9 \\
No slaughtered & $93,815,987$ & $107,497,830$ & 14.6 \\
Carcass weight (kg) & 89.4 & 92.3 & 3.2 \\
Production (tonness) & $8,386,510$ & $9,921,970$ & 18.3 \\
Offtake rate & 1.58 & 1.62 & 2.5 \\
Prod (kg)/Invent & 141.33 & 149.40 & 5.7 \\
\hline China/USA (\%) & & & \\
Carcass weight & 85.6 & 79.3 & -7.3 \\
Offtake rate & 76.6 & 88.9 & 16.1 \\
Prod (kg)/invent & 65.4 & 70.6 & 8.1 \\
\hline Source FAOSTAT [18. & & &
\end{tabular}

Source: FAOSTAT [18].
Table 2 Chinese and US poultry industry comparisons

\begin{tabular}{llll}
\hline & $\mathbf{2 0 0 0}$ & $\mathbf{2 0 1 2}$ & Change (\%) \\
\hline China & & & \\
Poultry Inventory* & $3,500,000,000$ & $5,300,000,000$ & 51.4 \\
Laying Hens & $1,895,000,000$ & $2,620,000,000$ & 38.3 \\
No slaughtered & $6,237,038,000$ & $9,178,430,000$ & 47.2 \\
Carcass weight (kg) & 1.35 & 1.38 & 2.2 \\
Production (tonnes) & $8,426,862$ & $12,667,151$ & 50.3 \\
Offtake rate & 1.78 & 1.73 & -2.8 \\
Prod (kg)/Invent & 2.41 & 2.39 & -0.7 \\
\hline USA & & & \\
Poultry Inventory* & $1,860,000,000$ & $1,929,600,000$ & 3.7 \\
Laying Hens & $328,300,000$ & $339,698,000$ & 3.5 \\
No slaughtered & $8,470,387,000$ & $8,650,779,000$ & 2.1 \\
Carcass weight (kg) & 1.65 & 1.97 & 19.6 \\
Production (tonnes) & $13,947,000$ & $17,038,000$ & 22.2 \\
Offtake rate & 4.55 & 4.48 & -1.6 \\
Prod (kg)/Invent & 7.50 & 8.83 & 17.8 \\
\hline China/USA (\%) & & & -14.6 \\
Carcass weight & 82.1 & 70.1 & -15.7 \\
Offtake rate & 39.1 & 38.6 & \\
Prod (kg)/invent & 32.1 & 27.1 & \\
\hline Source FAOSTAT [18. & & & \\
\hline
\end{tabular}

Source: FAOSTAT [18].

*Poultry inventory includes laying hens.

consequences [26-28]. Many argue in favor of accounting for the negative externalities resulting from this food animal production $[5,6,13,15,29,30]$. The risks of concentrated animal feeding operations are many and include driving the emergence and dissemination of antimicrobial resistance associated with the use of antimicrobials in animal feeds for growth promotion [13]. They also include groundwater and surface water contamination from the high quantities of animal waste produced. It is estimated that 500 million tons of solid waste are generated annually by animal feeding operations in the US [31]. A US Government Accountability Office report concluded that an 800,000 hog operation can generate more waste than the city of Philadelphia [32]. In China, it is estimated that 1.7 million metric tons [1.9 billion short tons] of animal waste were generated in 2010 [33].

One of the important aspects of intensive food animal production is the association with the use of antimicrobials in feeds. Antimicrobials are an essential component of clinical medicine that are threatened by increasing resistance to multiple drugs in major human pathogens. The reasons for increases in resistance are related to the overuse of these drugs in both clinical medicine and food animal production [34,35]. While there have been national and international programs to regulate clinical use of antimicrobials, only limited efforts have been 
made to reduce drug use in animal feeds [1,35,36]. Hence, regulation becomes an important mechanism to restrict use in feeds. In China, data indicate significant evidence of increasingly prevalent antibiotic resistance genes in the soils and wastewaters around Chinese livestock farms $[37,38]$. Currently, there are no official data on antibiotic use in Chinese agriculture. Some studies in the literature have noted a 2007 survey in which Chinese antimicrobial production was 210,000 metric tons [231,485 short tons] with $46 \%$ used in the livestock industry $[37,39]$. While this survey is reported in the literature in several studies, we have not been able to identify the survey and its methods.

In this paper, we seek to estimate the quantity of antimicrobials used in broiler poultry and swine feeds in Chinese food animal production. We use data on food animal antimicrobial utilization from the US assuming that Chinese practices are similar. This method does have shortcomings which we detail in the discussion. To our knowledge, there are no data or estimates of antimicrobial use in the poultry and swine production sectors in China.

\section{Methods}

To estimate antimicrobial use, we adopted the methodology of Mellon et al. (2001) [40]. Their estimates are close to estimates published by the Food and Drug Administration (FDA) using industry reported data [41]. This methodology generated estimates of the volume of antimicrobials by weight used in US food animal production based on FDA registration data, recommended usage of feed formulations, and production levels. The formula used by Mellon et al. for poultry is as follows:

Use $=\mathrm{N} \times \mathrm{P} \times \mathrm{F} \times \mathrm{D}$ where:

$\mathrm{N}=$ Number of animals in the stage

$\mathrm{P}=$ Percent of animals treated

$\mathrm{F}=$ Feed consumed per animal in each stage

$\mathrm{D}=$ Average dose of antimicrobials per pound of feed

Given that China has adopted US agricultural methods, we used this methodology for our estimates of antimicrobial use in animal feeds in China for both swine and poultry production [42]. For poultry, we specifically selected chicken while excluding ducks, geese, turkey, and quail. As discussed below, we estimate use in broiler chickens specifically.
It is also important to note that all results are by overall weight. Another method for calculating antimicrobial use involves calculating defined animal daily doses which are the average maintenance doses per day [43]. We adopted the methodology from Mellon et al. which was based on total weight.

\section{Poultry}

We used data from the statistics division of the Food and Agriculture Organization (FAOSTAT) to identify the number of chickens slaughtered in 2012, the latest data available [18]. This number was approximately 9.2 billion chickens. We also accounted for the number of laying hens since, as they were likely to be included in the number of chickens slaughtered. For 2012, the total number of layers was about 2.6 billion. In order to adjust FAOSTAT data to only broiler chickens, we assumed that each laying hen lived for an average of 1.5 years before slaughter. We then assumed two-thirds of these laying hens were slaughtered in 2012. The International Egg Commission provides an alternate estimate of the number of laying hens in China: 800- 1,000 million [44]. We used the Food and Agriculture Organization (FAO) data because the use of FAO data is widespread in the literature. Mellon et al. provided details on six combinations of antimicrobials used in each stage of poultry production. Poultry are produced in a Starting stage and a Growing/Finishing stage. Mellon et al. generated information on the average concentration of each combination per pound of feed and assumed that feeds contained $80 \%$ of the maximum concentration dose allowed by the FDA. In their tables, they also indicated the percent of broilers given feeds with each combination of antimicrobials and the pounds of feed consumed per bird in each stage of growth. Antimicrobial use in feed was calculated separately for each growth stage.

\section{Swine}

We used data from FAOSTAT to identify the number of swine slaughtered in China in 2012 which was approximately 671 million. Swine are also grown in several stages from birth to slaughter. We assumed about a $4 \%$ loss from starter to feeder phase and then assumed about a $2 \%$ loss from feeder to slaughter phase based on the Mellon et al. methodology. The number of swine in each stage is included in the tables below. The formula used by Mellon et al. is as follows:

Table 3 Poultry use by stage

\begin{tabular}{llllll}
\hline Stage & Number of Broilers & Totals $\mathbf{( g )}$ & Total $\mathbf{( k g )}$ & Percentage & Total/1000 animals \\
\hline Pre-starter/Starter & $7,431,763,333$ & $1,148,764,817$ & $1,148,765$ & $25 \%$ & 0.155 \\
Grower/Finsher & $7,431,763,333$ & $3,404,633,473$ & $3,404,633$ & $75 \%$ & 0.458 \\
Overall & $7,431,763,333$ & $4,553,398,290$ & $4,553,398$ & $100 \%$ & \\
\hline
\end{tabular}


Table 4 Breakdown by poultry antimicrobial combination

\begin{tabular}{|c|c|c|c|c|c|}
\hline \multicolumn{6}{|l|}{ Pre-starter and Starter Phases } \\
\hline Antimicrobial (AM) combination & Number of chickens & $\begin{array}{l}\text { Percent of } \\
\text { birds treated }\end{array}$ & Pounds of Feed & $\begin{array}{l}\text { g AM/lb } \\
\text { of feed }\end{array}$ & $\begin{array}{l}\text { Total } \\
\text { in } \mathbf{k g}\end{array}$ \\
\hline 1. bambermycin, amprolium, ethopabate, roxarsone & $7,431,763,333$ & $25 \%$ & 2.25 & 0.061680 & 257,845 \\
\hline 2. BMD, roxarsone, monensin & $7,431,763,333$ & $25 \%$ & 2.25 & 0.072120 & 301,488 \\
\hline 3. chlortetracycline, roxarsone & $7,431,763,333$ & $5 \%$ & 2.25 & 0.218160 & 182,398 \\
\hline 4. penicillin, amprolium, ethopabate & $7,431,763,333$ & $5 \%$ & 2.25 & 0.066840 & 55,883 \\
\hline 5. lincomycin, roxarsone, amprolium, ethopabate & $7,431,763,333$ & $15 \%$ & 2.25 & 0.066400 & 166,546 \\
\hline 6. virginiamycin, roxarsone, salinomycin & $7,431,763,333$ & $25 \%$ & 2.25 & 0.044160 & 184,605 \\
\hline Total & & & & & $1,148,765$ \\
\hline \multicolumn{6}{|l|}{ Grower and Finisher Phases } \\
\hline Antimicrobial combination & Number of chickens & $\begin{array}{l}\text { Percent of } \\
\text { birds treated }\end{array}$ & $\begin{array}{l}\text { Pounds of } \\
\text { feed }\end{array}$ & $\begin{array}{l}\text { g AM/lb } \\
\text { of feed }\end{array}$ & $\begin{array}{l}\text { Total } \\
\text { in } \mathbf{~ k g}\end{array}$ \\
\hline 1. bambermycin, lasalocid, roxarsone & $7,431,763,333$ & $28 \%$ & 6 & 0.06376 & 796,067 \\
\hline 2. erythromycin, arsanilic acid, zoalene & $7,431,763,333$ & $10 \%$ & 6 & 0.1184 & 527,952 \\
\hline 3. chlortetracycline, roxarsone, monensin & $7,431,763,333$ & $5 \%$ & 6 & 0.26216 & 584,493 \\
\hline 4. penicillin, roxarsone, zoalene & $7,431,763,333$ & $5 \%$ & 6 & 0.08356 & 186,299 \\
\hline 5. lincomycin, lasalocid, roxarsone & $7,431,763,333$ & $20 \%$ & 6 & 0.06416 & 572,186 \\
\hline 6. virginiamycin, monensin, roxarsone & $7,431,763,333$ & $28 \%$ & 6 & 0.05908 & 737,635 \\
\hline Total & & & & & $3,404,633$ \\
\hline
\end{tabular}

Use $=\mathrm{N}$ x F $x \mathrm{~T}$ x $\mathrm{C}$ where:

$\mathrm{N}=$ Number of animals in a group for the given stage

$\mathrm{F}=$ Estimated feed consumed per day

$\mathrm{T}=$ Duration in days in each phase that swine received antimicrobials in their feed

$\mathrm{D}=$ Dose of antimicrobials in the feed

Similar to poultry, Mellon et al. provided details on the percent of swine treated with each antimicrobial combination in each phase of growth, the pounds per day of feed consumed in each stage, average days administered, and the concentration of each antimicrobial combination in feed. They assumed antimicrobials were not given for the whole period of each stage. They also assumed the concentrations of antimicrobials in feeds were $70-85 \%$ of the maximum concentration allowed. Antimicrobial use was calculated for Starter, Feeder, Finisher, and Breeder phases. Because we were unable to identify the number of breeding pigs in China, we used an estimate based on the ratio of breeding pigs to number of slaughtered pigs provided in Mellon et al.

\section{Results \\ Poultry}

For poultry, our estimates suggest that slightly more than 4.5 million $\mathrm{kg}$ [9.9 million lbs] of antimicrobials were used in production for 2012 (Table 3). In the Prestarter and Starter phases, $25 \%$ of total antimicrobials were used. In the Grower and Finisher phases, 75\% of total antimicrobials were used.

A breakdown per combination of antimicrobials used is provided in Table 4. For the Pre-starter and Starter phases, antimicrobial combinations 1, 2, and 6 are used in the highest percentage of broilers, $25 \%$. Combination 2 results in the greatest overall weight used; $301,488 \mathrm{~kg}$ $[664,667 \mathrm{lbs}]$. For the Grower and Finisher phases, combinations 1 and 6 are used in the highest percentage of

Table 5 Swine use by stage

\begin{tabular}{llllll}
\hline Stage & Number of swine & Totals $\mathbf{( g )}$ & Total $\mathbf{( k g )}$ & Percentage & Total/1000 animals $\mathbf{( k g )}$ \\
\hline Starting & $711,743,169$ & $4,123,270,526$ & $4,123,271$ & $12.1 \%$ & 5.793 \\
Feeding & $684,368,429$ & $5,773,660,562$ & $5,773,661$ & $17.0 \%$ & 8.436 \\
Finishing & $670,949,440$ & $23,916,321,219$ & $23,916,321$ & $70.3 \%$ & 35.645 \\
Breeding & $50,393,463$ & $188,345,566$ & 188,346 & $0.6 \%$ & 3.738 \\
Total & & $34,001,597,873$ & $34,001,598$ & $100 \%$ & \\
\hline
\end{tabular}


Table 6 Breakdown by swine antimicrobial combination

\begin{tabular}{|c|c|c|c|c|c|c|}
\hline \multicolumn{7}{|l|}{ Starting Phase } \\
\hline $\begin{array}{l}\text { Antimicrobial(AM) } \\
\text { combination }\end{array}$ & $\begin{array}{l}\text { Total number } \\
\text { of swine }\end{array}$ & $\begin{array}{l}\text { Percent of } \\
\text { swine treated }\end{array}$ & $\begin{array}{l}\text { feed } \\
\text { (lbs/day) }\end{array}$ & $\begin{array}{l}\text { Avg } \\
\text { days used }\end{array}$ & $\begin{array}{l}\text { AM dose } \\
(\mathrm{g} / \mathrm{lb})\end{array}$ & $\begin{array}{l}\text { Total } \\
\text { in } \mathbf{~ k g}\end{array}$ \\
\hline 1. chlortetracycline sulfathiazole penicillin & $711,743,169$ & $20 \%$ & 2 & 35 & 0.100 & 996,440 \\
\hline 2. chlortetracycline sulfamethazine penicillin & $711,743,169$ & $20 \%$ & 2 & 35 & 0.100 & 996,440 \\
\hline 3. tylosin & $711,743,169$ & $40 \%$ & 2 & 35 & 0.025 & 498,220 \\
\hline 4. virginiamycin & $711,743,169$ & $4 \%$ & 2 & 35 & 0.004 & 7,972 \\
\hline 5. chlortetracycline & $711,743,169$ & $50 \%$ & 2 & 35 & 0.040 & 996,440 \\
\hline 6. oxytetracycline & $711,743,169$ & $40 \%$ & 2 & 35 & 0.025 & 498,220 \\
\hline 7. apramycin & $711,743,169$ & $10 \%$ & 2 & 14 & 0.065 & 129,537 \\
\hline Total & & & & & & $4,123,271$ \\
\hline \multicolumn{7}{|l|}{ Feeding Phase } \\
\hline Antimicrobial combination & $\begin{array}{l}\text { Total number } \\
\text { of swine }\end{array}$ & $\begin{array}{l}\text { Percent of } \\
\text { swine treated }\end{array}$ & $\begin{array}{l}\text { feed } \\
\text { (lbs/day) }\end{array}$ & $\begin{array}{l}\text { Avg } \\
\text { days used }\end{array}$ & $\begin{array}{l}\text { AM dose } \\
(\mathrm{g} / \mathrm{lb})\end{array}$ & $\begin{array}{l}\text { Total } \\
\text { in } \mathbf{k g}\end{array}$ \\
\hline 1. chlortetracycline sulfathiazole penicillin & $684,368,429$ & $10 \%$ & 4 & 38 & 0.1000 & $1,040,240$ \\
\hline 2. chlortetracycline sulfamethazine penicillin & $684,368,429$ & $7 \%$ & 4 & 15 & 0.1000 & 287,435 \\
\hline 3. tylosin sulfamethazine & $684,368,429$ & $5 \%$ & 4 & 38 & 0.0900 & 468,108 \\
\hline 4. carbadox & $684,368,429$ & $12 \%$ & 4 & 38 & 0.0225 & 280,865 \\
\hline 5. chlortetracycline & $684,368,429$ & $45 \%$ & 4 & 38 & 0.0350 & $1,638,378$ \\
\hline 6. tylosin & $684,368,429$ & $30 \%$ & 4 & 38 & 0.0175 & 546,126 \\
\hline 7. bacitracin & $684,368,429$ & $55 \%$ & 4 & 38 & 0.0150 & 858,198 \\
\hline 8. virginiamycin & $684,368,429$ & $4 \%$ & 4 & 38 & 0.0040 & 16,644 \\
\hline 9. arsanilic acid & $684,368,429$ & $2 \%$ & 4 & 38 & 0.0300 & 62,414 \\
\hline 10. bambermycin & $684,368,429$ & $2 \%$ & 4 & 38 & 0.0010 & 2,080 \\
\hline 11. oxytetracycline & $684,368,429$ & $25 \%$ & 4 & 38 & 0.0200 & 520,120 \\
\hline 12. oleandomycin & $684,368,429$ & $2 \%$ & 4 & 38 & 0.0040 & 8,322 \\
\hline 13. lincomycin & $684,368,429$ & $4 \%$ & 4 & 38 & 0.0080 & 33,288 \\
\hline 14. efrotomycin & $684,368,429$ & $2 \%$ & 4 & 38 & 0.0055 & 11,443 \\
\hline Total & & & & & & $5,773,661$ \\
\hline \multicolumn{7}{|l|}{ Finishing Phase } \\
\hline Antibiotic combination & $\begin{array}{l}\text { Total Number } \\
\text { of swine }\end{array}$ & $\begin{array}{l}\text { Percent of } \\
\text { swine treated }\end{array}$ & $\begin{array}{l}\text { feed } \\
\text { (lbs/day) }\end{array}$ & $\begin{array}{l}\text { Avg } \\
\text { days used }\end{array}$ & $\begin{array}{l}\text { AM dose } \\
(\mathrm{g} / \mathrm{lb})\end{array}$ & $\begin{array}{l}\text { Total } \\
\text { in } \mathbf{~ k g}\end{array}$ \\
\hline 1. chlortetracycline sulfathiazole penicillin & $670,949,440$ & $12 \%$ & 6.2 & 86 & 0.1250 & $5,366,254$ \\
\hline 2. tylosin sulfamethazine & $670,949,440$ & $5 \%$ & 6.2 & 72 & 0.1000 & $1,497,559$ \\
\hline 3. carbadox & $670,949,440$ & $15 \%$ & 6.2 & 45 & 0.0250 & 701,981 \\
\hline 4. chlortetracycline & $670,949,440$ & $55 \%$ & 6.2 & 86 & 0.0350 & $6,886,692$ \\
\hline 5. tylosin & $670,949,440$ & $30 \%$ & 6.2 & 86 & 0.0100 & $1,073,251$ \\
\hline 6. bacitracin & $670,949,440$ & $60 \%$ & 6.2 & 86 & 0.0250 & $5,366,254$ \\
\hline 7. arsanilic acid & $670,949,440$ & $3 \%$ & 6.2 & 86 & 0.0450 & 482,963 \\
\hline 8. bambermycin & $670,949,440$ & $6 \%$ & 6.2 & 86 & 0.0010 & 21,465 \\
\hline 9. oxytetracycline & $670,949,440$ & $30 \%$ & 6.2 & 86 & 0.0200 & $2,146,501$ \\
\hline 10. oleandomycin & $670,949,440$ & $5 \%$ & 6.2 & 86 & 0.0056 & 100,617 \\
\hline 11. efrotomycin & $670,949,440$ & $5 \%$ & 6.2 & 86 & 0.0073 & 129,684 \\
\hline 12. lincomycin & $670,949,440$ & $4 \%$ & 6.2 & 86 & 0.0100 & 143,100 \\
\hline Total & & & & & & $23,916,321$ \\
\hline
\end{tabular}

Breeding Phase 
Table 6 Breakdown by swine antimicrobial combination (Continued)

\begin{tabular}{|c|c|c|c|c|c|c|}
\hline Antimicrobial combination & $\begin{array}{l}\text { Total number } \\
\text { of swine }\end{array}$ & $\begin{array}{l}\text { Percent of } \\
\text { swine treated }\end{array}$ & $\begin{array}{l}\text { feed } \\
\text { (lbs/day) }\end{array}$ & Avg days used & $\begin{array}{l}\text { AM dose } \\
\text { (g/lb) }\end{array}$ & $\begin{array}{l}\text { Total } \\
\text { in kg }\end{array}$ \\
\hline 1. chlortetracycline & $50,393,463$ & $85 \%$ & 5 & 20 & 0.04 & 171,338 \\
\hline 2. arsanilic acid & $50,393,463$ & $5 \%$ & 5 & 20 & 0.045 & 11,339 \\
\hline 3. bambermycin & $50,393,463$ & $25 \%$ & 5 & 20 & 0.001 & 1,260 \\
\hline 4. oxytetracycline & $50,393,463$ & $25 \%$ & 5 & 14 & 0.005 & 4,409 \\
\hline Total & & & & & & 188,346 \\
\hline
\end{tabular}

broilers at $28 \%$. Combination 1 results in the highest overall weight used; 796,067 kg [1,755,027 lbs].

\section{Swine}

The results from our estimates shown in Table 5 indicate that 34 million $\mathrm{kg}$ [75 million lbs] of antimicrobials were used in the production of swine in 2012. About $70 \%$ of the total antimicrobial use was during the finishing phase of swine production. A breakdown per combination of antimicrobials used is provided in Table 6 . For the Starting phase, chlortetracycline alone was used in the highest percentage of swine, 50\%. Combinations 1 and 2 along with chlortetracycline resulted in the largest weights of antibiotics used in this stage: 996,440 kg $[2,196,774 \mathrm{lbs}]$. In the Feeding phase, bacitracin was used in 55\% of all swine. Chlortetracycline again resulted in the greatest weight used: 1,638,378 $\mathrm{kg}$ [3,612,005 lbs]. For the Finishing phase, bacitracin again was the most commonly used antibiotic, $60 \%$ of all swine. Chlortetracycline alone once again resulted in the largest weight used: $6,886,692 \mathrm{~kg}[15,182,557 \mathrm{lbs}]$. Finally, for the Breeding phase, chlortetracycline was used in $85 \%$ of swine. As a result, chlortetracycline contributed the largest weight to the overall total in this phase: $171,338 \mathrm{~kg}$ [377,736 lbs].

\section{By antibiotic class}

In Tables 7 and 8 below, we calculate the quantities of antimicrobials used, by weight, from major antibiotic classes. Mellon et al. provided concentrations of each antimicrobial in each antimicrobial combination in Tables 4 and 6. We then followed the formulas and assumptions listed in the methods section to arrive at the totals by class as listed in Tables 7 and 8 below.

Table 7 Antimicrobial use by class in poultry

\begin{tabular}{ll}
\hline Antibiotic Class & Total $\mathbf{( k g )}$ \\
\hline Tetracyclines & 613,120 \\
Penicillins & 61,312 \\
Macrolides & 164,985 \\
Coccidiostats* & $3,407,220$ \\
Arsenicals* & $2,879,624$ \\
\hline
\end{tabular}

* Many arsenical compounds function as coccidiostats.
Table 7 indicates that coccidiostats and arsenicals are the most common antimicrobials used in poultry production by weight. Macrolides, penicillins, and tetracyclines are also used, with resulting implications for antimicrobial resistance and public health.

For swine, Table 8 indicates that tetracyclines, sulfonamides, macrolides, and penicillins are the largest antimicrobial classes by weight used in production. These classes of antimicrobials are also used frequently in human medicine.

\section{Discussion}

The results of our calculations indicate that overall, 4.5 million $\mathrm{kg}$ [9.9 million lbs] of antimicrobials were used for poultry production and 34 million $\mathrm{kg}$ [75 million $\mathrm{lbs}$ ] for swine production in China for 2012. These results use US data on food animal antimicrobial utilization with the assumption that Chinese methods are similar. Arsenicals account for 2.9 million $\mathrm{kg}$ [6.4 million lbs] in poultry production and only $556,000 \mathrm{~kg}$ [1.2 million lbs] in swine production. Calculations based on these two species alone account for 38.5 million $\mathrm{kg}$ [84.9 million lbs] of antimicrobials. Additionally, our methodology does not include all types of meat production (notably all avians), and thus total antimicrobial use, by weight, may be considerably larger for aggregate food animal production. This is important to note given China also produces large quantities of duck: 2,205,926,000 birds for 2012 [18]. Furthermore, as annual production and consumption increases, this model would predict that increasing volumes of antimicrobials would also be used each year [18].

A comparison to US antimicrobial consumption is useful. It is argued that the current US consumption of

Table 8 Antimicrobial use by class in swine

\begin{tabular}{ll}
\hline Antibiotic Class & Total $\mathbf{( k g})$ \\
\hline Sulfonamides & $4,457,557$ \\
Tetracyclines & $16,336,823$ \\
Penicillins & $1,737,362$ \\
Macrolides & $3,209,370$ \\
Aminoglycosides & 129,537 \\
Arsenicals & 556,716 \\
\hline
\end{tabular}


antimicrobials in both human medicine and animal feeds is too high, unnecessary, and harmful $[35,45,46]$. The total use of antimicrobials by weight for 2011 was 17 million $\mathrm{kg}$ [37.6 million lbs] [41,47]. Of this total, animal production accounted for 13.6 million $\mathrm{kg}$ [29.9 million lbs]. Our estimates of antimicrobial use in swine and poultry production in China are 38.5 million $\mathrm{kg}$ [ 84.9 million lbs]. This number is almost three times the amounts used for food animal production in the United States. However, it should be noted that this number is consistent with the higher production of swine in China [18].

The data on which we based our calculations has limitations. First, we do not have information on the extent to which food animal production in China is similar to that in the US. However, we have evidence that the shift from small farms to larger animal feeding operations is happening at a rapid pace, as discussed in the introduction. In addition, we do not have exact knowledge of the antibiotic regimens used in Chinese poultry and swine production. The lack of a monitoring and regulatory framework makes identification of such regimens difficult in China [36]. Moreover, we do not know how farm sizes may alter the use of antibiotics in feeds on Chinese farms. Given that industrial scale farming has increasing market share, we felt it was acceptable to generalize from the Mellon et al. model.

Furthermore, we assumed that animal feeds in 2014 Chinese food animal production were similar to the Mellon et al model. Antimicrobial usage in animal feeds can change. For example, in 2005, the FDA began restricting fluoroquinolone and later, arsenical use in poultry feeds [48-52]. Additionally, not all antimicrobials that are used in animal feeds were included in the original analysis by Mellon et al. Notably, they failed to include quinolones (enrofloxacin, norofloxacin, ofloxacin), which are clinically important drugs that monitoring systems continue to detect in poultry feeds [53,54]. Moreover, in China, multiple studies have shown residual antimicrobials in livestock manure including the presence of quinolones [55-57]. While the FDA regulates American livestock antimicrobial use to an extent, we are not aware of such regulation in China. Direct comparisons of residual antimicrobial masses in manure and the environment between the US and China are not available. Finally, quinupristin/dalfopristin was not included in these estimates, and it is known to be used in US poultry feeds. Hence, these agents should be accounted for in future research.

\section{Conclusions}

In this paper, we estimated the quantity of antimicrobials used in Chinese swine and poultry production at 38.5 million $\mathrm{kg}$ [84.9 million lbs]. We anticipate challenges to this number and have outlined limitations in the data and methods above, notably the application of US antimicrobial utilization estimates to China. As with the estimate by Mellon et al. in the US, we hope this paper will stimulate discussion and collection of information on antimicrobial utilization in animal feeds in China. Ultimately, better information is needed to reach and ensure sound policy decisions on these practices.

\section{Abbreviations \\ CAFO: Concentrated animal feeding operation; FDA: Food and drug administration; FAO: Food and agriculture organization; FAOSTAT: Statistics division of the food and agriculture organization.}

\section{Competing interests}

The authors declare that they have no competing interests.

\section{Authors' contributions}

VK designed the study, collected the data, conducted the data analysis, and drafted the manuscript. JO assisted in study conception, data acquisition, interpretation of the data, and critically evaluated the manuscript. ES assisted in study conception, study design, data acquisition, interpretation of the data, and critically evaluated the manuscript. All authors read and approved the final manuscript.

\section{Authors' information}

VK is a General Preventive Medicine Resident at the Johns Hopkins University Bloomberg School of Public Health. JO is the Coordinator of the Pro-Poor Livestock Policy Initiative at the Food and Agriculture Organization. ES is a Professor of Environmental Health Sciences and holds joint appointments in Health Policy and Management as well as in Epidemiology at the Johns Hopkins University Bloomberg School of Public Health.

\section{Author details}

'Johns Hopkins University Bloomberg School of Public Health, 615 N. Wolfe Street, Room WB602, Baltimore, MD 21205, USA. Food and Agriculture Organization, Room C-510, Viale delle Terme di Caracalla, Rome 00153, Italy. 3 Johns Hopkins University Bloomberg School of Public Health, 615 N. Wolfe Street, Room E6644, Baltimore, MD 21205, USA

Received: 2 September 2014 Accepted: 13 March 2015

Published online: 28 April 2015

\section{References}

1. Silbergeld EK, Davis $M$, Leibler JH, Peterson AE. One reservoir: redefining the community origins of antimicrobial-resistant infections. Med Clin North Am. 2008:92:1391-407.

2. Stokstad EL, Jukes TH, Pierce J, Page AC, Franklin AL. The multiple nature of the animal protein factor. J Biol Chem. 1949;180:647-54.

3. Starr MP, Reynolds DM. Streptomycin resistance of coliform bacteria from turkeys fed streptomycin. Am J Public Health Nations Health. 1951;41:1375-80.

4. Elliott SD, Barnes EM. Changes in serological type and antibiotic resistance of Lancefield group D streptococci in chickens receiving dietary chlortetracycline. J Gen Microbiol. 1959;20:426-33.

5. The Business of Broilers: Hidden Costs of Putting a Chicken on Every Grill. The Pew Charitable Trusts; 2013. [http://www.pewtrusts.org/en/researchand-analysis/reports/2013/12/20/the-business-of-broilers-hidden-costs-ofputting-a-chicken-on-every-grill].

6. Pew Commission on Industrial Farm Animal Production: Putting Meat on The Table: Industrial Farm Animal Production in America. The Pew Charitable Trusts; 2008. [http://www.ncifap.org/].

7. Pi C, Rou Z, Horowitz S. Fair or Fowl? Industrialization of Poultry Production in China. Institute for Agriculture and Trade Policy; 2014. [http://www.iatp. org/documents/fair-or-fowl-industrialization-of-poultry-production-in-china].

8. Izat A, Colberg M, Reiber M, Adams M, Skinner J, Cabel M, et al. Effects of different antibiotics on performance, processing characteristics, and parts yield of broiler chickens. Poult Sci. 1990;69:1787-91.

9. Feighner SD, Dashkevicz MP. Subtherapeutic levels of antibiotics in poultry feeds and their effects on weight gain, feed efficiency, and bacterial cholyltaurine hydrolase activity. Appl Environ Microbiol. 1987;53:331-6. 
10. Graham JP, Boland JJ, Silbergeld E. Growth promoting antibiotics in food animal production: an economic analysis. Public Health Rep. 2007;122:79-87.

11. 2012 Census of Agriculture. USDA, National Agricultural Statistics Service; 2014. [http://www.agcensus.usda.gov/Publications/2012/\#full_report]

12. MacDonald JM, McBride WD. The Transformation of US Livestock Agriculture: Scale, Efficiency, and Risks. USDA Economic Research Service; 2009. [http://www.ers.usda.gov/publications/eib-economic-informationbulletin/eib43.aspx]

13. Gurian-Sherman D. CAFOs Uncovered: The Untold Costs of Confined Animal Feeding Operations. Union of Concerned Scientists; 2008. [http:// www.ucsusa.org/food_and_agriculture/our-failing-food-system/industrialagriculture/cafos-uncovered.html]

14. Martinez S. Vertical Coordination in the Pork and Broiler Industries: Implications for Pork and Chicken Products. United States Department of Agriculture; 1999. [Agricultural Economic Report]. [http://www.ers.usda.gov/ publications/aer-agricultural-economic-report/aer777.aspx]

15. Big Chicken: Pollution and Industrial Poultry Production In America. The Pew Charitable Trusts; 2011. [http://www.pewenvironment.org/news-room/ reports/big-chicken-pollution-and-industrial-poultry-production-in-america85899361375]

16. Daniel CR, Cross AJ, Koebnick C, Sinha R. Trends in meat consumption in the USA. Public Health Nutr. 2011;14:575-83.

17. $W H O \mid$ 3. Global and regional food consumption patterns and trends [http://www.who.int/nutrition/topics/3_foodconsumption/en/index4.html]

18. FAOSTAT [http://faostat3.fao.org/faostat-gateway/go/to/home/E]

19. Earth Policy Institute Data Center [http://www.earth-policy.org/data_center/]

20. Schneider M, Sharma S. China's Pork Miracle? Institute for Agriculture and Trade Policy; 2014. [http://www.iatp.org/blog/201402/bracing-for-impactsas-china-enters-industrial-meat-complex]

21. Meat Consumption in China Now Double That in the United States [http://www.earth-policy.org/plan_b_updates/2012/update102]

22. Industrialization of China's Pork Supply Chain. Industry Note \#329. Food \& Agribusiness Research and Advisory. Rabobank International; September, 2012.

23. Oh SH, See MT. Pork preference for consumers in China, Japan and South Korea. Asian-Australas J Anim Sci. 2012;25:143-50.

24. USDA Foreign Agricultural Service Production, Supply and Distribution Online [http://apps.fas.usda.gov/psdonline/]

25. Woolsey M, Beckman C, Zhang J. China - Peoples Republic of Poultry and Products Annual 2011. USDA Foreign Agricultural Service; 2011. [Global Agricultural Information Network]. [http://gain.fas.usda.gov/Recent\%20GAIN\%20Publications/Poultry\%20and\%20Products\%20Annual_Beijing_China\%20-\%20Peoples\%20Republic\%20of_9-15-2011.pdf]

26. Watts J. Chinese farms cause more pollution than factories, says official survey. The Guardian 2010. [http://www.theguardian.com/environment/ 2010/feb/09/china-farms-pollution]

27. Cang L, Wang $Y$, Zhou D, Dong Y. Heavy metals pollution in poultry and livestock feeds and manures under intensive farming in Jiangsu Province, China. J Environ Sci (China). 2004;16:371-4.

28. Sun B, Zhang L, Yang L, Zhang F, Norse D, Zhu Z. Agricultural non-point source pollution in china: causes and mitigation measures. AMBIO. 2012;41:370-9.

29. Burkholder J, Libra B, Weyer P, Heathcote S, Kolpin D, Thorne PS, et al. Impacts of waste from concentrated animal feeding operations on water quality. Environ Health Perspect. 2006;115:308-12.

30. Donham KJ, Wing S, Osterberg D, Flora JL, Hodne C, Thu KM, et al. Community health and socioeconomic issues surrounding soncentrated animal feeding operations. Environ Health Perspect. 2006;115:317-20.

31. Koneswaran G, Nierenberg D. Global farm animal production and global warming: impacting and mitigating climate change. Environ Health Perspect. 2008;116:578-82.

32. Concentrated Animal Feeding Operations: EPA Needs More Information and a Clearly Defined Strategy to Protect Air and Water Quality from Pollutants of Concern [http://www.gao.gov/products/GAO-08-944]

33. Qiu H, Liao S, Jing Y, Luan J. Regional differences and development tendency of livestock manure pollution in China. Huan Jing Ke Xue. 2013;34:2766-74.

34. Marshall B, Levy S. Food animals and antimicrobials: impacts on human health. Clin Microbiol Rev. 2011;24:718-33.
35. Antibiotic Resistance Threats in the United States, 2013. Centers for Disease Control and Prevention; 2013. [http://www.cdc.gov/drugresistance/threatreport-2013/]

36. Maron DF, Smith TJ, Nachman KE. Restrictions on antimicrobial use in food animal production: an international regulatory and economic survey. Glob Health. 2013;9:48.

37. Zhu Y-G, Johnson TA, Su J-Q, Qiao M, Guo G-X, Stedtfeld RD, et al. Diverse and abundant antibiotic resistance genes in Chinese swine farms. Proc Natl Acad Sci. 2013;110:3435-40.

38. Cheng W, Chen H, Su C, Yan S. Abundance and persistence of antibiotic resistance genes in livestock farms: a comprehensive investigation in eastern China. Environ Int. 2013;61:1-7.

39. Hvistendahl M. China takes aim at rampant antibiotic resistance. Science. 2012;336:795.

40. Mellon M, Benbrook C, Benbrook KL. Hogging It!: Estimates of Antimicrobial Abuse in Livestock. Union of Concerned Scientists USA. 2001. [http:// www.ucsusa.org/food_and_agriculture/our-failing-food-system/industrialagriculture/hogging-it-estimates-of.html]

41. CVM Updates - FDA Annual Report on Antimicrobials Sold or Distributed for Food-Producing Animals in 2011 [http://www.fda.gov/AnimalVeterinary/ NewsEvents/CVMUpdates/ucm338178.htm]

42. Gerber P, Chilonda P, Franceschini G, Menzi H. Geographical determinants and environmental implications of livestock production intensification in Asia. Bioresour Technol. 2005;96:263-76.

43. DANMAP. 2012 - Use of Antimicrobial Agents and Occurrence of Antimicrobial Resistance in Bacteria from Food Animals, Food and Humans in Denmark. 2013.

44. The World Egg Industry - a few facts and figures [https://www.internationalegg.com/corporate/eggindustry/details.asp?id=18]

45. Huttner B, Samore M. Outpatient antibiotic use in the United States: time to "get smarter.". Clin Infect Dis. 2011;53:640-3.

46. Hicks L, Taylor T, Hunkler R. U.S. outpatient antibiotic prescribing, 2010. N Engl J Med. 2013;368:1461-2.

47. Record High Antibiotic Sales for Meat and Poultry Production [http:// www.pewhealth.org/other-resource/record-high-antibiotic-sales-for-meatand-poultry-production-85899449119]

48. CVM Updates - Approval Withdrawn for Abbott Laboratories' Poultry Fluoroquinolone Drugs [http://www.gpo.gov/fdsys/pkg/FR-2001-04-30/html/ 01-10067.htm]

49. Product Safety Information - 3-Nitro (Roxarsone) and Chicken [http:// www.fda.gov/AnimalVeterinary/SafetyHealth/ProductSafetyInformation/ ucm 257540.htm]

50. Strom S. F.D.A. Bans three arsenic drugs used in poultry and pig feeds. N Y Times 2013. [http://www.nytimes.com/2013/10/02/business/fda-bans-threearsenic-drugs-used-in-poultry-and-pig-feeds.html]

51. CVM Updates - FDA/CVM Proposes To Withdraw Poultry Fluoroquinolones Approval [http://www.fda.gov/AnimalVeterinary/SafetyHealth/ RecallsWithdrawals/ucm042012.htm]

52. CVM Updates - FDA Takes Significant Steps to Address Antimicrobial Resistance [http://www.fda.gov/AnimalVeterinary/NewsEvents/CVMUpdates/ ucm378166.htm]

53. Love DC, Halden RU, Davis MF, Nachman KE. Feather meal: a previously unrecognized route for reentry into the food supply of multiple pharmaceuticals and personal care products (PPCPS). Environ Sci Technol. 2012;46:3795-802.

54. Silbergeld EK, Graham J, Price LB. Industrial food animal production, antimicrobial resistance, and human health. Annu Rev Public Health. 2008:29:151-69.

55. Li Y, Zhang X, Li W, Lu X, Liu B, Wang J. The residues and environmental risks of multiple veterinary antibiotics in animal faeces. Environ Monit Assess. 2013;185:2211-20.

56. Zhou L-J, Ying G-G, Liu S, Zhang R-Q, Lai H-J, Chen Z-F, et al. Excretion masses and environmental occurrence of antibiotics in typical swine and dairy cattle farms in China. Sci Total Environ. 2013;444:183-95.

57. Wei R, Ge F, Huang S, Chen M, Wang R. Occurrence of veterinary antibiotics in animal wastewater and surface water around farms in Jiangsu Province, China. Chemosphere. 2011;82:1408-14. 